\title{
Front Matter: Volume 11458
}

, "Front Matter: Volume 11458," Proc. SPIE 11458, Saratov Fall Meeting 2019: Laser Physics, Photonic Technologies, and Molecular Modeling, 1145801 (9 April 2020); doi: 10.1117/12.2570908

SPIE Event: Saratov Fall Meeting 2019: VII International Symposium on Optics and Biophotonics, 2019, Saratov, Russian Federation 


\title{
PROGRESS IN BIOMEDICAL OPTICS AND IMAGING

Saratov Fall Meeting 2019

Laser Physics, Photonic Technologies, and Molecular Modeling

\author{
Vladimir L. Derbov
}

Editor

23-27 September 2019

Saratov, Russian Federation

Sponsored by

Saratov State University (Russian Federation)

Research Center of Biotechnology of the Russian Academy of Sciences (Russian Federation)

The Optical Society

art photonics GmbH (Germany)

AVESTA Projects, Ltd. (Russian Federation)

Becker \& Hickl GmbH (Germany)

INJECT RME LLC (Russian Federation)

LLC SPE Nanostructured Glass Technology (Russian Federation)

Technical Cosponsor and Publisher

SPIE

Volume 11458 
The papers in this volume were part of the technical conference cited on the cover and title page. Papers were selected and subject to review by the editors and conference program committee. Some conference presentations may not be available for publication. Additional papers and presentation recordings may be available online in the SPIE Digital Library at SPIEDigitalLibrary.org.

The papers reflect the work and thoughts of the authors and are published herein as submitted. The publisher is not responsible for the validity of the information or for any outcomes resulting from reliance thereon.

Please use the following format to cite material from these proceedings:

Author(s), "Title of Paper," in Saratov Fall Meeting 2019: Laser Physics, Photonic Technologies, and Molecular Modeling, edited by Vladimir L. Derbov, Proceedings of SPIE Vol. 11458 (SPIE, Bellingham, WA, 2020) Seven-digit Article CID Number.

ISSN: 1605-7422

ISSN: 2410-9045 (electronic)

ISBN: 9781510637207

ISBN: 9781510637214 (electronic)

Published by

SPIE

P.O. Box 10, Bellingham, Washington 98227-0010 USA

Telephone +1 3606763290 (Pacific Time) · Fax +1 3606471445

SPIE.org

Copyright (C) 2020, Society of Photo-Optical Instrumentation Engineers.

Copying of material in this book for internal or personal use, or for the internal or personal use of specific clients, beyond the fair use provisions granted by the U.S. Copyright Law is authorized by SPIE subject to payment of copying fees. The Transactional Reporting Service base fee for this volume is $\$ 21.00$ per article (or portion thereof), which should be paid directly to the Copyright Clearance Center (CCC), 222 Rosewood Drive, Danvers, MA 01923. Payment may also be made electronically through CCC Online at copyright.com. Other copying for republication, resale, advertising or promotion, or any form of systematic or multiple reproduction of any material in this book is prohibited except with permission in writing from the publisher. The CCC fee code is 1605$7422 / 20 / \$ 21.00$.

Printed in the United States of America.

Publication of record for individual papers is online in the SPIE Digital Library.

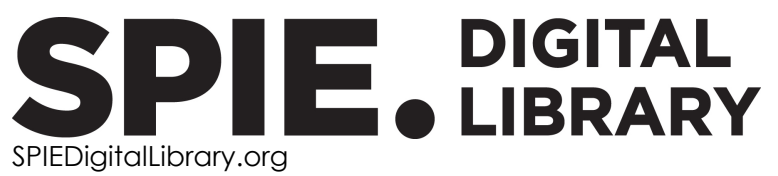

Paper Numbering: Proceedings of SPIE follow an e-First publication model. A unique citation identifier (CID) number is assigned to each article at the time of publication. Utilization of CIDs allows articles to be fully citable as soon as they are published online, and connects the same identifier to all online and print versions of the publication. SPIE uses a seven-digit CID article numbering system structured as follows:

- The first five digits correspond to the SPIE volume number.

- The last two digits indicate publication order within the volume using a Base 36 numbering system employing both numerals and letters. These two-number sets start with $00,01,02,03,04$, 05, 06, 07, 08, 09, 0A, OB ... 0Z, followed by 10-1Z, 20-2Z, etc. The CID Number appears on each page of the manuscript. 


\title{
Contents
}

\author{
vii Authors \\ ix Conference Committee \\ xiii Introduction \\ xvii Conference Organizers
}

LASER SYSTEMS, LASER AND PHOTONIC TECHNOLOGIES

$1145802 \quad$ Dynamics of VCSEL under triangular current modulation [1 1458-47]

$1145803 \quad$ Comparison of nanoseconds and picoseconds laser ablation for microfabrication of planar slow-wave structures for D-band vacuum electronic devices with sheet electron beam [11458-41]

$1145804 \quad$ Laser ablation and other manufacturing approaches for flexible antenna fabrication [11458-40]

$1145805 \quad$ Multi-mode manipulation of microscopic objects using acousto-optical deflector [11458-36]

$1145806 \quad$ Light stimulated anomalous self-blocking of all-optical poling [1 1458-32]

1145807 3D above threshold modelling of MIR quantum cascade laser with high index contrast photonic crystal structure [11458-29]

1145808 The experimental estimation of temporal and power parameters of the near-surface laser plasma forming [1 1 $458-27]$

$1145809 \quad$ Nanosecond laser-induced photomodification of gold nanostars of various sizes [11458-21]

11458 OA Digital holographic endoscopy with a single-mode fiber as a reference channel [11458-3]

11458 OB Photophoresis-based laser manipulation of airborne particles using structured laser beams [11458-1]

11458 OC Charging titanium microparticles with femtosecond laser pulses [1 1458-6]

11458 OD Acceleration measurement by spectrum of interference signal of self-mixing laser [1 1458-2]

11458 OE Experimental study of pointed sapphire needles for interstitial laser therapy [11458-8] 
NONLINEAR OPTICS, BEAMS, AND PULSE PROPAGATION

11458 OF Transformation of reflection and transmission matrices when changing the basis of two orthogonal polarizations [11458-25]

11458 OG Phase modulation effects in the case of electromagnetically induced transparency [1 1458-1 1]

$11458 \mathrm{OH} \quad$ Effect of lead oxide concentration on the generation of light harmonics in glass media [1 1458-17]

11458 Ol The propagation of a special shape optical pulse in an anisotropic inhomogeneous medium with dispersion [11458-19]

$11458 \mathrm{~J} \quad$ Experimental investigation of nonlinear spiral phase plates [1 1458-12]

QUANTUM OPTICS AND ENTANGLED STATES

11458 OK Influence of a detuning and Kerr nonlinearity on atom-atom entanglement in a double twophoton Jaynes-Cummings model [11458-15]

$11458 \mathrm{OL} \quad$ Thermal entanglement in a double Jaynes-Cummings model [1 1458-13]

\section{ADVANCED POLARIZATION AND CORRELATION TECHNOLOGIES}

11458 OM OCT probing of highly porous polylactide matrices using estimations of the integrated scandepth-dependent diffuse reflectivity [1 1458-44]

$114580 \mathrm{~N} \quad$ Polarization-optical study of the magneto-optical characteristics of petroleum products [1 1458-33]

$1145800 \quad$ Reference-free low-coherence reflectometry under condition of low spectral selectivity of the detection system [11458-31]

11458 OP Photo-induced disturbance of the operation of polarization optical devices [11458-20]

\section{SPECTROSCOPY AND MOLECULAR MODELING}

$114580 Q \quad$ On calculations of metastable and Rydberg states of diatomic beryllium molecule and antiprotonic helium atom [1 1458-46]

11458 OR Joint application of Raman and optical absorption spectroscopy to determine concentrations of heavy metal ions in water using artificial neural networks [1 1458-38]

iv 
11458 OS Ellipsometry of biological objects in the mode of attenuated total reflection (ATR) using a circularly polarized laser light [1 1458-26]

11458 OT Theoretical research of SWCN with chitosan dimer using vibrational spectroscopy [11458-23]

11458 OU Determination of conformational composition of proline in the gas phase [1 1458-22]

11458 OV Manifestation of Fermi resonance in Raman spectra of micellar aqueous solutions of sodium octanoate [11458-9]

$11458 \mathrm{OW}$ The influence of the structure of phosphorus-based ligands on the stability of europium complexes using spectrophotometric titration [11458-18]

\section{SOURCES AND APPLICATIONS OF TERAHERTZ RADIATION}

11458 OX Deceleration of terahertz plasma waves in tapered graphene-insulator-graphene heterostructure [11458-35]

11458 OY Generation of terahertz radiation in a system of coupled semiconductor lasers [11458-34]

METAMATERIALS, LOW-DIMENSIONAL AND BAND-GAP STRUCTURES

$11458 \mathrm{OZ} \quad$ Vertical heterostructures based monolayers of dielectric and semiconductor graphene-like 2D materials: atomic structure, energy stability and electronic properties [1 1458-43]

1145810 Study of dielectric properties of resistive thin-film coatings based on silicon nitride compositions [1 1458-39]

$1145811 \quad$ Nanoscale oscillator on the base of single-walled carbon nanotube with internal fullerenes $\mathrm{C}_{36}$ and $\mathrm{C}_{80}$ [11458-37]

1145812 Photoconductance of quasi-2D random layers of anatase nanoparticles near the edge of the fundamental absorption band [1 1458-30]

1145813 Polaritons and diffraction on the layer of asymmetric hyperbolic metamaterial [11458-7]

1145814 On photon tunneling through a bandgap structure [11458-14] 
Proc. of SPIE Vol. 11458 1145801-6

Downloaded From: https://www.spiedigitallibrary.org/conference-proceedings-of-spie on 25 Apr 2023 Terms of Use: https://www.spiedigitallibrary.org/terms-of-use 


\section{Authors}

Numbers in the index correspond to the last two digits of the seven-digit citation identifier (CID) article numbering system used in Proceedings of SPIE. The first five digits reflect the volume number. Base 36 numbering is employed for the last two digits and indicates the order of articles within the volume. Numbers start with 00, 01, 02, 03, 04, 05, 06, 07, 08, 09, OA, OB...0Z, followed by 10-1Z, 20-2Z, etc.

\author{
Akchurin, Garif G., 09 \\ Akchurin, Georgy G., 09 \\ Al Salihi, Hind A., 11 \\ Aleksandrova, Polina V., OE \\ Alonova, M. V., OM \\ Amelchenko, Yuliya, OS \\ Anchikov, Dmitry A., 02 \\ Atman, Petr, OP \\ Bagrov, Ivan, ON \\ Bashkirov, Eugene K., OK, OL \\ Baydachenko, Vladislav A., 08 \\ Bessonov, Dmitry A., 03 \\ Boreysho, A. S., OC \\ Borisova, Nataliya E., OW \\ Burikov, Sergey, OR, OV \\ Burmak, Liudmila, $O A$ \\ Chuluunbaatar, G., $0 Q$ \\ Chuluunbaatar, O., $0 Q$ \\ Daniaeva, Julia, OP \\ Davidovich, Michael V., 13, 14 \\ Derbov, V. L., OQ \\ Dmitriev, Alexei E., OG \\ Dobdin, S. YU., OD \\ Dolenko, Sergey, OR, OV \\ Dolenko, Tatiana, OR, OV \\ Dolganova, Irina N., OE \\ Dubman, Anna B., OB \\ Dzhafarov, A. V., OD \\ Elkin, Nikolay N., 07 \\ Fayad, Mohammed A., 11 \\ Galkin, Alexander, 03 \\ Galushka, Viktor V., 03, 04, 10 \\ Gerasimenko, Alexander Yu., OT \\ Glukhova, Olga E., OZ \\ Góźdź, A., OQ \\ Gridin, Georgy E., OJ \\ Gusev, A. A., OQ \\ Isaev, Igor, OR \\ Isaeva, A. A., OM, 00 \\ Isaeva, E. A., OM, 00 \\ Khanadeev, Vitaly A., 09 \\ Khlebtsov, Nikolai G., 09 \\ Khonina, Svetlana N., OJ \\ Khramov, Vladimir N., 08 \\ Kochkurov, L. A., OY, 12 \\ Kolosov, Dmitriy A., $\mathrm{OZ}$ \\ Korotkov, Leonid A., OW \\ Kozhevnikov, llya O., 03, 04, 10 \\ Kozlov, A., 05
}

Krassovitskiy, P. M., OQ

Krents, Anton A., 02

Kurlov, Vladimir N., OE

Kushneruk, Snezhana A., 09

Kutsenko, Svetlana, ON, OP

Laptinskiy, Kirill, OR

Logachev, Valentin I., OJ

Machikhin, Alexander S., 05

Makarkin, Stanislav A., 10

Martynaov, Grigoriy N., 05

Mazhirina, YU. A., OY

Mitin, A. V., OQ

Moiseev, Anton Vladimirovich, OI, ON

Moiseeva, Natalya Michailovna, OF, OI

Molevich, Nonna E., 02

Morozov, M. YU., OX

Mukhina, Elena E., OE

Napartovich, Anatoly P., 07

Parshkov, Oleg M., OG

Pavlov, Anton M., 03, 04, 10

Plastinin, I. V., OV

Pogoda, A. P., OC

Popov, V. V., OX

Porfirev, Alexey P., OB, OJ

Ryskin, Nikita M., 03

Sadchikova, K. A., OD

Sakharov, Valentin K., 03

Samoilenko, Alena, OP

Sarmanova, Olga, OR

Savelyev, Mikhail S., OT

Savin, A. V., OC

Sementin, V. V., OC

Serdobintsev, Alexey A., 03, 04, 10

Serdobintsev, P. YU., OC

Sergeev, A. A., OC

Shcherbakova, Natalia E., OT, OU

Shikunova, Irina A., OE

Shmygin, Dmitriy S., OZ

Shunaev, Vladislav, 11

Simonenko, Andrey $\vee ., 09$

Sin'ko, Dmitry $\vee_{\text {., }} 08$

Sipivy, Dmitry, ON

Skripal, An. V., OD

Slepchenkov, Mikhail M., OZ, 11

Smirnov, Vitaly A., $06, \mathrm{OH}$

Starodubov, Andrey V., 03, 04, 10

Sumyanova, Tsagana B., OW

Ten, Galina N., OT, OU

Torgashov, Roman A., 03 
Trifonov, Nikita, OR

Tuchin, Valery $\vee ., 09$

Ushakova, E. V., 12

Ushakova, O. V., OM

Vinitsky, S. I., OQ

Volchkov, S. S., 12

Vostrikova, Liubov I., 06, $\mathrm{OH}$

Vysotsky, Dmitry V., 07

Yablokova, Anastasiya A., 05

Yatsishen, Valeriy, OS

Zakirova, Gladiz G., OW

Zaytsev, Kirill I., OE

Zimnyakov, D. A., 0M, 00, 12

Zotov, Arsen K., OE

Zykova, Lidia, OA 


\title{
Conference Committee
}

\author{
Symposium Chair
}

Valery V. Tuchin, Saratov State University (Russian Federation) and Tomsk State University, (Russian Federation) and Institute of Precision Mechanics and Control, RAS (Russian Federation)

\section{Conference Chairs}

Lev M. Babkov, Saratov State University (Russian Federation) Michael V. Davidovich, Saratov State University (Russian Federation) Vladimir L. Derbov, Saratov State University (Russian Federation) Olga E. Glukhova, Saratov State University (Russian Federation) Dmitry A. Zimnyakov, Saratov State Technical University (Russian Federation)

\section{Conference Program Committee}

Robert R. Alfano, City College of New York (United States) Stefan Andersson-Engels, Tyndall National Institute (Ireland) Oleg V. Angelsky, Chernivtsi National University (Ukraine) Lev M. Babkov, Saratov State University (Russian Federation) Victor N. Bagratashvili, Institute of Laser and Information Technologies, RAS (Russian Federation)

Claude Boccara, École Supérieure de Physique et de Chimie Industrielles de la Ville de Paris (France)

Tatiana G. Bourova, Saratov State Pedagogical Institute (Russian Federation)

Nikolai V. Burenin, Institute of Applied Physics, RAS (Russian Federation)

Alexander V. Bykov, University of Oulu (Finland)

Nadezhda A. Davydova, Institute of Physics, NAS (Ukraine)

Vladimir L. Derbov, Saratov State University (Russian Federation)

Alexander V. Doronin, Yale University (United States)

Victor L. Furer, Kazan Civil Engineer Academy (Russian Federation)

Zhang Gang, Institute of High-Performance Computing, Agency for Science, Technology and Research (Singapore)

Georgi N. Georgiev, Saints Cyril and Methodius University (Bulgaria)

Lev A. Gribov, Vernadsky Institute of Geochemistry and Analytical Chemistry, RAS (Russian Federation)

Andrei D. Grigoriev, St. Petersburg Electrotechnical University LETI (Russian Federation)

Alexander V. Gorokhov, Samara State University (Russian Federation) Steven L. Jacques, Tufts School of Engineering (United States)

Bogos B. Joulakian, Université Metz (France)

Alexander P. Kuznetsov, Institute of Radio-Engineering, RAS (Russian Federation) 
Alexander M. Lerer, South Federal University (Russian Federation)

Ming-Fa Lin, National Cheng Kung University (Taiwan)

Marian Marciniak, National Institute of Telecommunications (Poland)

Galina N. Maslyakova, Saratov State Medical University

(Russian Federation)

Leonid A. Melnikov, Saratov State Technical University

(Russian Federation)

Josef Modelsky, Warsaw University of Technology (Poland)

Albert G. Nasibulin, Skolkovo Institute of Science and Technology

(Russian Federation)

Igor S. Nefedov, Aalto University, Espoo (Finland)

Alexander P. Nizovtsev, Institute of Physics of NASB (Belarus)

Alexander I. Nosich, Kharkov Institute of Radio-Engineering and

Electronics, NAS Ukraine (Ukraine)

Alexey P. Popov, University of Oulu (Finland)

Yuri V. Popov, M.V. Lomonosov Moscow State University (Russian Federation)

Tatiana R. Prytkova, Cloud Pharmaceuticals (United States)

Vladimir P. Ryabukho, Saratov State University (Russian Federation), Institute of Precision Mechanics and Control, RAS (Russian Federation)

Nikita M. Ryskin, Saratov State University (Russian Federation)

Alexander P. Sviridov, Institute of Photon Technologies of Federal Scientific Research Center "Crystallography and Photonics", RAS (Russian Federation)

Dmitry I. Trubetskov, Saratov State University (Russian Federation)

Valery V. Tuchin, Saratov State University (Russian Federation) and Tomsk State University, (Russian Federation) and Institute of Precision Mechanics and Control, RAS (Russian Federation)

Olga V. Ushakova, Saratov State Technical University (Russian Federation)

Alexander G. Ushenko, Chernivtsi National University (Ukraine)

Dmitry S. Umreiko, Belarus State University (Belarus)

Sergei I. Vinitsky, Joint Institute for Nuclear Research (Russian Federation)

Lihong Wang, Caltech (United States)

Irina V. Zaporotskova, Volgograd State University (Russian Federation)

Aleksey M. Zheltikov, M.V. Lomonosov Moscow State University (Russian Federation)

\section{Session Chairs}

1 Laser Physics and Photonics XXI

Vladimir L. Derbov, Saratov State University (Russian Federation)

2 Spectroscopy and Molecular Modeling XX

Lev M. Babkov, Saratov State University (Russian Federation)

3 Low-Dimensional Structures IX

Olga E. Glukhova, Saratov State University (Russian Federation) 
4 Advanced Polarization and Correlation Technologies in Biomedicine and Material Science VI

Dmitry A. Zimnyakov, Saratov State Technical University (Russian Federation)

5 Electromagnetics of Microwaves, Submillimeter and Optical Waves IXX Michael V. Davidovich, Saratov State University (Russian Federation) 
Proc. of SPIE Vol. 11458 1145801-12

Downloaded From: https://www.spiedigitallibrary.org/conference-proceedings-of-spie on 25 Apr 2023 Terms of Use: https://www.spiedigitallibrary.org/terms-of-use 


\title{
Introduction
}

The Seventh International Symposium on Optics and Biophotonics (Saratov Fall Meeting, SFM19) was held in Saratov, Russian Federation, 23-27 September 2019 with more than 500 participants from Russian Federation, United States, Canada, Europe, and Asian countries. It covered a wide range of modern problems of fundamental and applied optics, laser physics, photonics, and biomedical optics, as well as related fields of material science.

The Proceedings of the symposium are published in three SPIE volumes. The present volume includes selected papers of the following conferences and workshops organized in the framework of the symposium:

\author{
Laser Physics and Photonics XXI \\ Vladimir L. Derbov (Chair) \\ Spectroscopy and Molecular Modeling XX \\ Lev M. Babkov (Chair) \\ Low-Dimensional Structures IX \\ Olga E. Glukhova (Chair)
}

Advanced Polarization and Correlation Technologies in Biomedicine and Material Science VI

Dmitry A. Zimnyakov (Chair)

Electromagnetics of Microwaves, Submillimeter and Optical Waves IXX

Michael V. Davidovich (Chair)

The volume begins with the section reporting on recent studies in laser systems and laser and photonic technologies. Alongside the studies of VCSEL dynamics and modeling of MIR quantum cascade laser with high index contrast photonic crystal structure, a variety of laser applications is presented, including acceleration measurement, laser ablation for microfabrication technology, manipulation of microscopic objects, light-stimulated anomalous blocking of alloptical poling, near-surface plasma formation and laser-induced photomodification of gold nanoparticles. Of particular interest for ecology and navigation are the results on laser manipulation of airborne particles.

The next section is devoted to nonlinear optics, beam and pulse propagation including self-modulation effects in electromagnetically induced transparency, generation of high-order harmonics in glass media, polarization and anisotropy effects, as well as experimental studies of spiral beams generation.

Our meeting traditionally gives the floor to discussing urgent problems of quantum optics. In the present volume, the papers related to quantum optics are focused 
on entangled quantum states of light, which are considered as qubits for quantum computers.

Advanced polarization and correlation technologies in this volume are represented by four papers devoted to low coherence reflectometry and OCT probing of porous materials, on the one hand, and more traditional techniques of polarization optical analysis, on the other hand. The techniques reported here can be applied to both biomedicine and material science.

Spectroscopy and molecular modeling has traditionally been an important part of the Saratov Fall Meetings, both past and present. The appropriate section of this volume combined the traditional molecular spectroscopy of new objects, relevant to modern photonics and biophysics, with theoretical analysis of more specific objects of study, e.g., weakly bound dimer systems that have no chemical bond in the traditional sense and exist as bound systems only due to electron correlations. Following the trend of recent years, a considerable amount of experimental work was reported.

A special section is devoted to sources and applications of terahertz radiation, thus reflecting rapidly growing multidisciplinary interest to the $\mathrm{THz}$ range. In this section deceleration of terahertz plasma waves in tapered graphene-insulatorgraphene heterostructure and generation of terahertz radiation in a system of coupled semiconductor lasers are considered.

Finally, last but not the least, a section on metamaterials, low dimensional and band-gap structures covers a wide range of studies of electronic and optical properties of graphene-based systems, heterostructures and low-dimensional nanostructures. Theoretical papers on electrodynamics of protonic systems were also included in this section, since they mainly refer to the electromagnetics of metamaterials and left-handed media.

This was the second volume of Saratov Fall Meeting 2019. The preface to the first volume Optical and Nano-Technologies for Biology and Medicine (Proceedings volume 11457), edited by Elina A. Genina and Valery V. Tuchin, provided the reader with thorough and impressive information about the entire event of Saratov Fall Meeting 2019.

On behalf of SFM19 organizers, the editor of this volume thanks all authors for their contributions to the symposium, especially the plenary, invited and Internet lecturers for their exciting presentations. We are also grateful to all the sponsoring organizations and programs that efficiently supported the meeting: Saratov State University (Russian Federation); Research Center of Biotechnology RAS (Russian Federation); SPIE - The International Society of Photo-Optical Instrumentation Engineers; The Optical Society; Art Photonics GmbH (Germany); Avesta Projects Ltd. (Russian Federation); Becker \& Hickl GmbH (Germany); RME INJECT, LLC 
(Russian Federation); LLC SPE Nanostructured Glass Technology (Russian Federation).

Vladimir L. Derbov

Proc. of SPIE Vol. 11458 1145801-15

Downloaded From: https://www.spiedigitallibrary.org/conference-proceedings-of-spie on 25 Apr 2023 Terms of Use: https://www.spiedigitallibrary.org/terms-of-use 
Proc. of SPIE Vol. 11458 1145801-16

Downloaded From: https://www.spiedigitallibrary.org/conference-proceedings-of-spie on 25 Apr 2023 Terms of Use: https://www.spiedigitallibrary.org/terms-of-use 


\title{
Conference Organizers
}

\author{
Saratov State University (Russian Federation) \\ Research-Educational Institute of Optics and Biophotonics of Saratov State \\ University (Russian Federation) \\ International Research-Educational Center of Optical Technologies for Industry \\ and Medicine "Photonics" of Saratov State University (Russian Federation) \\ Institute of Biochemistry \& Physiology of Plants \& Microorganisms of the RAS \\ (Russian Federation) \\ Institute of Precision Mechanics and Control of the RAS (Russian Federation) \\ Saratov State Medical University named after V.I. Razumovsky \\ (Russian Federation) \\ Volga Region Center of New Information Technologies of Saratov State University \\ (Russian Federation) \\ Tomsk State University (Russian Federation) \\ ITMO University (Russian Federation) \\ Bauman Moscow State Technical University (Russian Federation) \\ Institute of Solid-State Physics of the RAS (Russian Federation) \\ Prokhorov Institute of General Physics of the RAS (Russian Federation) \\ Research Center of Biotechnology of the RAS (Russian Federation) \\ Biomedical Photonics Committee of Chinese Optical Society (China) \\ SPIE Student Chapters of: \\ Saratov State University (Russian Federation), \\ Bauman Moscow State Technical University (Russian Federation), \\ Institute of Solid-State Physics of the RAS (Russian Federation), and \\ Samara University (Russian Federation) \\ OSA Student Chapters of: \\ Saratov State University (Russian Federation) and \\ Bauman Moscow State Technical University (Russian Federation)
}


Proc. of SPIE Vol. 11458 1145801-18

Downloaded From: https://www.spiedigitallibrary.org/conference-proceedings-of-spie on 25 Apr 2023 Terms of Use: https://www.spiedigitallibrary.org/terms-of-use 